\title{
An efficient construction of quinazolin-4(3H)-ones under microwave irradiation
}

\author{
Feng Li, Yiqing Feng, Qingqing Meng, Wenhua Li, Zhiming Li, Quanrui Wang,* \\ and Fenggang Tao \\ Department of Chemistry, Fudan University, 220 Handan Road, Shanghai 200433, China \\ E-mail: qrwang@fudan.edu.cn
}

\begin{abstract}
The highly accelerated Niementowski synthesis of quinazolin-4(3H)-one and quinazolin-2,4dione derivatives under microwave irradiation is reported. Compared to the conventional conditions, this new method shows the advantages of a good substrate tolerance, and a clean and rapid conversion. The method has been successfully applied for the construction of the key intermediate of iressa.
\end{abstract}

Keywords: Quinazolin-4(3H)-ones, microwave irradiation, Iressa

\section{Introduction}

Various quinazolin-4-ones, quinazolin-2,4-diones and their derivatives are well known to possess an array of physiological activities, e. g. anticancer, muscal relaxant, hypnotic, antiinflammatory, antineoplastic, diuretic, and antihypertensive activities, and are widely used in pharmaceuticals. ${ }^{1}$ Examples include the anticancer compound trimetrexate, the sedative methaqualone, the alpha adrenergic receptor antagonist such as doxazosin and the antihypertensive agent ketanserin. As a consequence, they have been very attractive targets in synthetic chemistry in recent years. In particular, gefinitib, i.e. $N$-(3-chloro-4-fluorophenyl)-7-methoxy-6-(3-morpholinopropoxy) quinazolin-4-amine (traded as Iressa, ZD1839, see Figure 1) which can be synthesized by elaboration of 6-benzyloxy-7-methoxyquinazolin-4(3H)-one 9, has been recognized as a tyrosine kinase inhibitor of the epidermal growth factor receptor and has been clinically used against cell lung cancer with ever increasing popularity. ${ }^{2}$ 


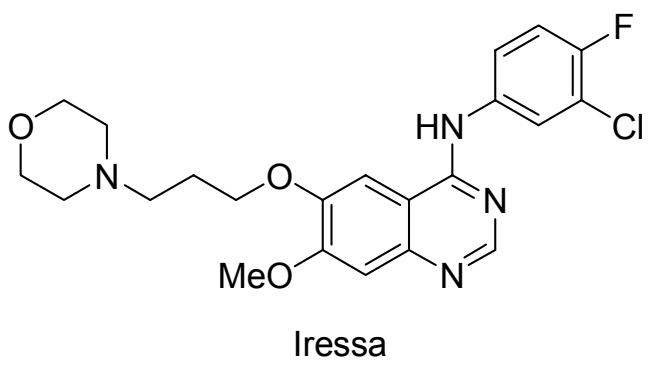

\section{Figure 1}

In accordance with the significance of quinazolin-4(3H)-ones, various synthetic methods have been developed for the construction of this kind of fused heterocycles. ${ }^{3,4}$ Many quinazolines can be prepared from 2-aminobenzaldehyde, 2-aminophenyl ketones or anthranilic acids. Typically, quinazolin-4(3H)-ones are prepared from an anthranilic acid or its derivative, e.g. 2amimobenzonitrile and an amide under acidic catalytic conditions by heating them at $200{ }^{\circ} \mathrm{C}$, termed as the Niementowski synthesis. A recent paper has reported a $\mathrm{Yb}(\mathrm{OTf})_{3}$-catalyzed onepot synthesis of quinazolin-4(3H)-ones from anthranilic acid, anilines and orthoesters (or formic acid) under solvent-free conditions. ${ }^{5}$ The reaction was completed in several minutes and the temperature was lowered to 60 or $80{ }^{\circ} \mathrm{C}$, providing good to excellent yields of the products, but the method seems to be restricted to the synthesis of 2-aryl substituted quinazolin- $4(3 H)$-ones. Certainly, there are still many other possible variations. For example, 4H-3,1-benzoxazin-4-ones react with primary amines at or above room temperature to give a variety of 4-quinazolinones. ${ }^{6}$ Although the reported methods are valuable in varying degree, some of them still suffer from limitations like unsatisfactory or variable yields, lengthy reaction time, unsatisfactory substrate tolerance and tedious work-up procedure. Benzoxazin-4-ones themselves have to be prepared from anthranilic acids and are rather moisture-sensitive, highly hygroscopic, and prone to deteriorate at higher temperatures. It is therefore of interest to develop a reliable synthetic strategy for the construction of such fused heterocycles.

Microwave-assisted chemical synthesis is proving to be a powerful technique for increasing the output of chemical synthesis. ${ }^{6}$ The advantages of the microwave method over classical techniques including a strikingly enhanced reaction rate, improved yields and cleaner products have been well documented. ${ }^{7}$ There are also a few esoteric examples describing the benefits of using microwave irradiation for the construction of the quinazolin-4(3H)-one core. ${ }^{8}$ For example, Besson $^{8 c}$ has reported the microwave-mediated condensation of anthranilic acids with formamide, to give, via an $o$-amidine intermediate, quinazolin-4(3H)-ones. Recently, we are engaged in the use of microwave irradiation for the preparation of the usually uneasy attainable compounds such as diaryl ethers and diaryl sulfides. ${ }^{9}$ In continuation of our interest in reactions where conventional heating was limited, with recent focus on the fused heterocyclic skeleton serving as building blocks for the preparation of compounds with pronounced pharmaceutical value like Iressa, we furthered our investigation on the use of microwave irradiation for 
synthesizing diverse quinazolinones based on the modified Niementowski reaction. In this paper, we demonstrate that, under microwave irradiation, both anthranilic acids and anthranilamides react smoothly with a range of amides and ketones or urea leading to quinazolinone derivatives of high purity in moderate to excellent yields with a simple work-up. In the course of the work, three types of quinazolinone derivatives were obtained, namely 2-substituted quinazolin-4(3H)ones 1, 2,2-disubstituted 2,3-dihydroquinazolin-4(1H)-ones 2 and 1H,3H-quinazolin-2,4-dione 3 (Figure 2).<smiles>[R]c1nc2ccccc2c(=O)[nH]1</smiles>

1<smiles>[R]C1([R])NC(=O)c2ccccc2N1</smiles>

2<smiles>O=c1[nH]c(=O)c2ccccc2[nH]1</smiles>

3

Figure 2

\section{Results and Discussion}

Our work was initiated with the reaction between anthranilamide $4 \mathbf{a}$ and formamide 5a. To optimize the reaction conditions, the irradiation power, the reactants ratio and reaction time were variably investigated. We were pleased to find that the reaction provided quinazolin- $4(3 H)$-one 1a in $93 \%$ yield after 5 min of irradiation at $300 \mathrm{~W}$ with the reactants ratio of 4a:5a at 1:5 (Table 1 , entry 1) in the presence of one equivalent of acetic acid. In comparison, a conventional thermal heating of this reaction at reflux in ethanol for $1 \mathrm{~h}$ gave $86 \%$ yield of the product under acetic acid catalysis. ${ }^{10}$ Encouraged by this result, the reactivity of other amides toward the Niementowski reaction was examined and the results are summarized in Table 1. The addition of less than a stoichiometric amount of the acid is helpful for the reaction. For formamide and acetamide 5b, glacial acetic acid is strong enough to catalyze the reaction. But for benzamide 5c, a stronger acid such as $p$ - $\mathrm{TsOH}$ is necessary. As expected, $\mathbf{5 b}$ demonstrated a much lower reactivity, probably due to steric hindrance. However, the moderate yield of $\mathbf{1 b}$ could be achieved when the mole ratio of $\mathbf{4 a}, \mathbf{5 b}$ and the acetic acid was 1:10:1 under microwave irradiation of $500 \mathrm{~W}$ for $20 \mathrm{~min}$ (Table 1, entry 2). Instead of an aliphatic amide, the aromatic substrate 5c was employed to test the scope of the protocol. To our surprise, under comparable conditions as for 5a, the 2-phenyl substituted 1c was isolated in 63\% yield after $10 \mathrm{~min}$ irradiation at $300 \mathrm{~W}$ with the addition of 0.04 equivalents of $p$-TsOH as the catalyst (Table 1 , entry 3). Increasing the amount of the acid did not improve the yields significantly. Further, the Niementowski reaction could also be carried out for 2-cyanoacetamide 5d, providing a satisfactory yield of the product $\mathbf{1 d}$ under comparable conditions, yet at a much lower microwave output without any acid added in only 5 minutes (Table 1, entry 4). 
We then switched to the use of the cheaper substrate anthranilic acid $\mathbf{4 b}$ for the desired Niementowski reaction. The activities of 5a-c were sequentially examined according to the comparable conditions for anthranilamide. We obtained the 2 -substituted quinazolin-4(3H)-one products $1 \mathrm{a}-\mathrm{c}$ in $81 \%, 46 \%$, and $17 \%$ yields, respectively. These were generally lower than that achieved in the case of anthranilamide, especially when the aromatic amide $\mathbf{5 c}$ was used.

Table 1. Acid-catalyzed coupling of anthranilamide or anthranilic acid with amide under microwave irradiation $^{\mathrm{a}}$

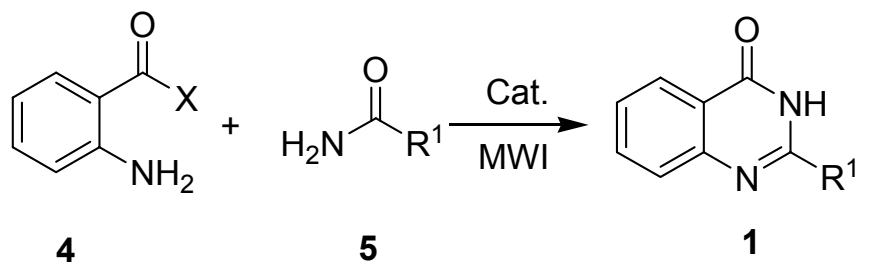

4a. $X=\mathrm{NH}_{2}$; 4b: $X=\mathrm{OH}$; 1a, 5a: $\mathrm{R}^{1}=\mathrm{H} ; \mathbf{1 b}, \mathbf{5 b}: \mathrm{R}^{1}=\mathrm{Me} ; \mathbf{1 c}, \mathbf{5 c}: \mathrm{R}^{1}=\mathrm{Ph}$; 1d, 5d: $\mathrm{R}^{1}=$ $\mathrm{CH}_{2} \mathrm{CN}$

\begin{tabular}{|c|c|c|c|c|c|c|c|c|}
\hline Entry & 4 & 5 & $\begin{array}{l}\text { Substrates } \\
\text { ratio }(\mathbf{4 : 5})\end{array}$ & $\begin{array}{l}\text { Cat. } \\
\text { (equiv.) }\end{array}$ & $\begin{array}{l}\text { Power } \\
(\mathrm{W})\end{array}$ & $\begin{array}{l}\text { Time } \\
(\min )\end{array}$ & Product $^{\mathrm{b}}$ & $\begin{array}{l}\text { Yield of } 1^{\mathrm{c}} \\
(\%)\end{array}$ \\
\hline 1 & $4 a$ & $5 \mathbf{a}$ & $1: 5$ & $\begin{array}{l}\text { HOAc } \\
(1.0)\end{array}$ & 300 & 5 & $1 \mathrm{a}$ & 93 \\
\hline 2 & $4 a$ & $5 b$ & $1: 10$ & $\begin{array}{l}\text { HOAc } \\
(1.0)\end{array}$ & 500 & 20 & $1 b$ & 77 \\
\hline 3 & $4 a$ & $5 c$ & $1: 5$ & $\begin{array}{l}p-\mathrm{TsOH} \\
(0.04)\end{array}$ & 300 & 10 & $1 \mathrm{c}$ & 63 \\
\hline 4 & $4 a$ & $5 d$ & $1: 1$ & none & 60 & 5 & $1 d$ & 78 \\
\hline 5 & $4 b$ & $5 \mathbf{a}$ & $1: 5$ & $\begin{array}{l}\text { HOAc } \\
(1.0)\end{array}$ & 300 & 5 & $1 \mathrm{a}$ & 81 \\
\hline 6 & $4 b$ & $5 \mathbf{b}$ & $1: 10$ & $\begin{array}{l}\text { HOAc } \\
(1.0)\end{array}$ & 500 & 20 & $1 b$ & 46 \\
\hline 7 & $4 b$ & $5 c$ & $1: 5$ & $\begin{array}{l}p-\mathrm{TsOH} \\
(0.04)\end{array}$ & 300 & 10 & $1 \mathrm{c}$ & 17 \\
\hline
\end{tabular}

${ }^{\mathrm{a}}$ Reaction of $1 \mathrm{mmol}$ scale, MW power and reaction time as specified.

${ }^{b}$ All products were identified on the basis of their NMR and IR spectra.

${ }^{\mathrm{c}}$ Isolated yield based on 4

Mechanistically, the reaction may proceed via an $o$-amidine intermediate $\mathbf{6}$ as illustrated in Scheme 1. The first step in this reaction involves the acid catalyzed formation of intermediate 6 by reaction of the amino group in anthranilamide or anthranilic acid with the carbonyl group of the amide, followed by the nucleophilic attack of the nitrogen nucleophile at the carboxylic or 
amido carbonyl group which is activated by protonation to produce the product $\mathbf{1}$ upon elimination of amine or water or two molecules of water.
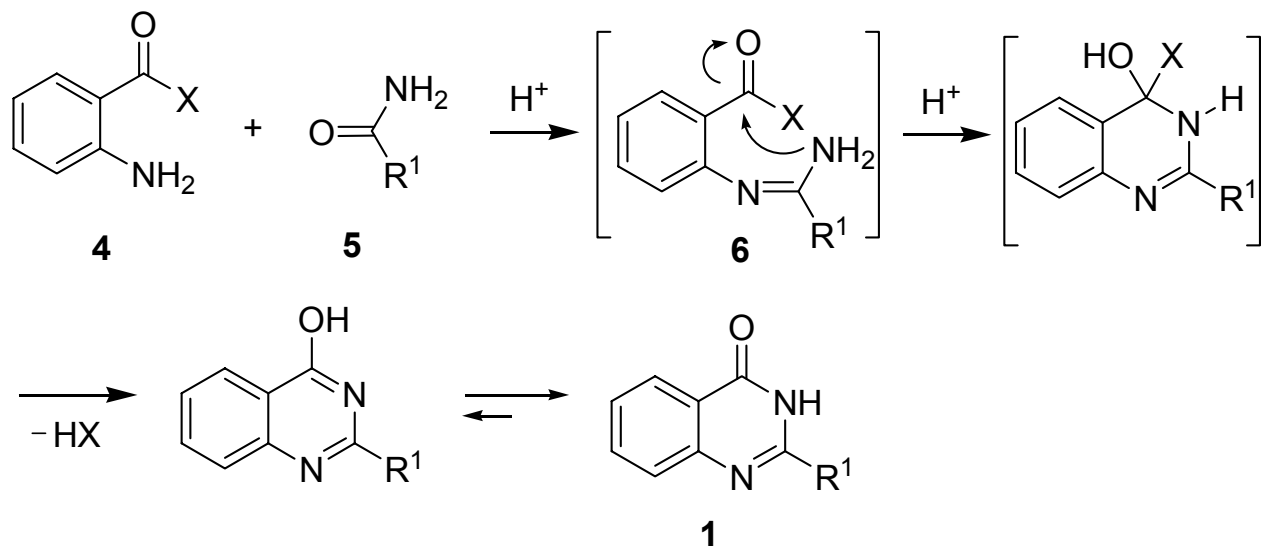

\section{Scheme 1}

Encouraged by this success, we became interested in applying this protocol for other carbonyl compounds, such as ketones. Due to the superior performance in the Niementowski reaction, anthranilamide 4a was selected as the substrate and was subjected to reaction with different kinds of ketones 7 (Table 2). As a result, different 2,2-disubstituted 2,3dihydroquinazolin-4(1H)-ones 2 were obtained in yields ranging from 66 to 95\% (Table 2, entries 1-4). This indicates a dramatic reduction in reaction time as compared with the conventional thermal process. ${ }^{4 \mathrm{~g}, 4 \mathrm{~h}}$ The use of an aliphatic ketone gave excellent isolated yields, and with cyclohexanone the reaction proceeded equally well, providing the 2-spiro substituted 2,3-dihydroquinazolin-4(1H)-one 2c. However, application of benzophenone afforded $\mathbf{2 d}$ with a low yield of $66 \%$ even though the irradiation time was prolonged to 20 min (Table 2, entry 4). To the best of our knowledge, there is no report on the Niementowski reaction using an electronically unfavorable substrate like benzophenone under classical heating conditions.

It's interesting that $\mathbf{2 d}$ was isolated as a complex with one molecule of DMF, which is probably formed via the intermolecular hydrogen bond.

Next, attention was focused on the reaction with urea and the results are given in Table 3 . As can be seen, both $\mathbf{4 a}$ and $\mathbf{4 b}$ can be used, affording $1 H, 3 H$-quinazolin-2,4-dione $\mathbf{3}$ in good yields. Compound $\mathbf{3}$ has been reported to be a key precursor for the synthesis of reversible inhibitors of the gastric $\left(\mathrm{H}^{+} / \mathrm{K}^{+}\right)$-ATPase. ${ }^{11}$ Again, 4a exhibited a greater activity towards the cyclocondensation. Since urea undergoes decomposition at high temperatures, the reaction had to be performed in solvents such as DMSO. 
Table 2. Acid-catalyzed coupling of anthranilamide with ketones under microwave irradiation ${ }^{\mathrm{a}}$

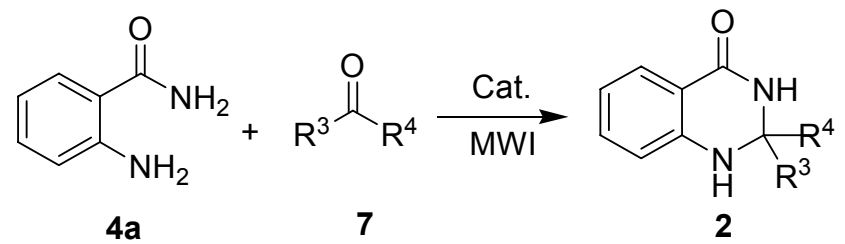

\begin{tabular}{|c|c|c|c|c|c|c|c|}
\hline Entry & $\begin{array}{l}\text { Ketone } \\
7\end{array}$ & $\begin{array}{l}\text { Substrates } \\
\text { ratio }(4: 7)\end{array}$ & $\begin{array}{l}\text { Cat. } \\
\text { (equiv.) }\end{array}$ & $\begin{array}{l}\text { Power } \\
\text { (W) }\end{array}$ & $\begin{array}{l}\text { Time } \\
(\min )\end{array}$ & Product $^{\mathrm{b}}$ & $\begin{array}{l}\text { Yield } \\
\text { of } 2^{\mathrm{c}} \\
(\%)\end{array}$ \\
\hline 1 & & $1: 40$ & $\begin{array}{l}p- \\
\text { TsOH } \\
(0.02)\end{array}$ & 60 & 5 & & 91 \\
\hline 2 & & $1: 20$ & $\begin{array}{l}p- \\
\text { TsOH } \\
(0.02)\end{array}$ & 60 & 5 & & 95 \\
\hline 3 & & $1: 5$ & none & 300 & 10 & & 91 \\
\hline 4 & & $1: 5$ & $\begin{array}{l}p- \\
\mathrm{TsOH} \\
(0.08)\end{array}$ & 300 & 20 & & 66 \\
\hline
\end{tabular}

${ }^{\text {a }}$ Reaction on $1 \mathrm{mmol}$ scale, MW power and reaction time as specified.

${ }^{\mathrm{b}}$ All products were identified on the basis of their NMR and IR spectra.

${ }^{\mathrm{c}}$ Isolated yield based on 4

Having established the advantages of the microwave irradiation approach for the construction of the quinazoline core, we decided to apply the protocol for the synthesis of the key intermediate of Iressa (Scheme 2). Thus, 5-benzyloxy-4-methoxy-2-aminobenzamide 8, prepared from isovanillin according to a known procedure, ${ }^{12}$ was reacted with formamide in the presence of one equivalent of acetic acid under microwave irradiation at $300 \mathrm{~W}$ for $5 \mathrm{~min}$, providing the 6,7-disubstituted quinazolin-4(3H)-one 9 in $87 \%$ isolated yield. Compared to the thermal heating method, which utilized the 6-benzyloxy-7-methoxyquinazolin-4(3H)-one and formamide which required $5 \mathrm{~h}$ of heating at $190{ }^{\circ} \mathrm{C}$, the developed method gave a significant reduction in reaction time. ${ }^{13}$ Treatment of 9 with an excess amount of phosphoryl chloride yielded the 4-chloro substituted quinazoline $\mathbf{1 0}$ in $68 \%$ yield, which was further converted to the 4-anilino substituted 11 by reaction with 3-chloro-4-fluoroaniline in 93\% yield. Debenzylation of 11 was smoothly accomplished upon hydrogenolysis over $\mathrm{Pd} / \mathrm{C}$ in ethanol wherein the deprotected product 12 was 
obtained in $85 \%$ yield. Finally, the 6-OH substituted quinazoline 12 was subjected to etherification with 4-(3-chloropropyl)morpholine ${ }^{14}$ upon heating at $90{ }^{\circ} \mathrm{C}$ in DMF for $3.5 \mathrm{~h}$ in the presence of a mild base, providing $72 \%$ yield of Iressa as a pale yellow solid.

Table 3. Acid-catalyzed coupling of anthranilamide/anthranilic acid with urea under microwave irradiation $^{\mathrm{a}}$

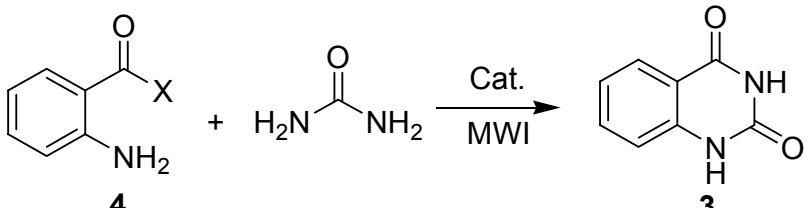

\begin{tabular}{lllllll}
\hline Entry & $\mathbf{4}$ & Solvent & $\begin{array}{l}\text { Cat. } \\
\text { (equiv.) }\end{array}$ & $\begin{array}{l}\text { Power } \\
(\mathrm{W})\end{array}$ & $\begin{array}{l}\text { Time } \\
(\mathrm{min})\end{array}$ & $\begin{array}{l}\text { Yield }^{\mathrm{b}}(\%) \\
\mathbf{3}(\%)\end{array}$ \\
\hline 1 & $\mathbf{4 a}$ & DMSO & $\begin{array}{l}\text { HOAc } \\
(1)\end{array}$ & 300 & 5 & 88 \\
2 & $\mathbf{4 b}$ & DMSO & $\begin{array}{l}\text { HOAc } \\
(1)\end{array}$ & 300 & 10 & 66 \\
\hline
\end{tabular}

${ }^{a}$ Reaction on $1 \mathrm{mmol}$ scale. With the substrates ratio of $4 \mathbf{a}$ to urea $1: 4$. Reaction time as specified.

${ }^{\mathrm{b}}$ Isolated yield based on 4 . The structure 3 was ascertained by IR and NMR data.
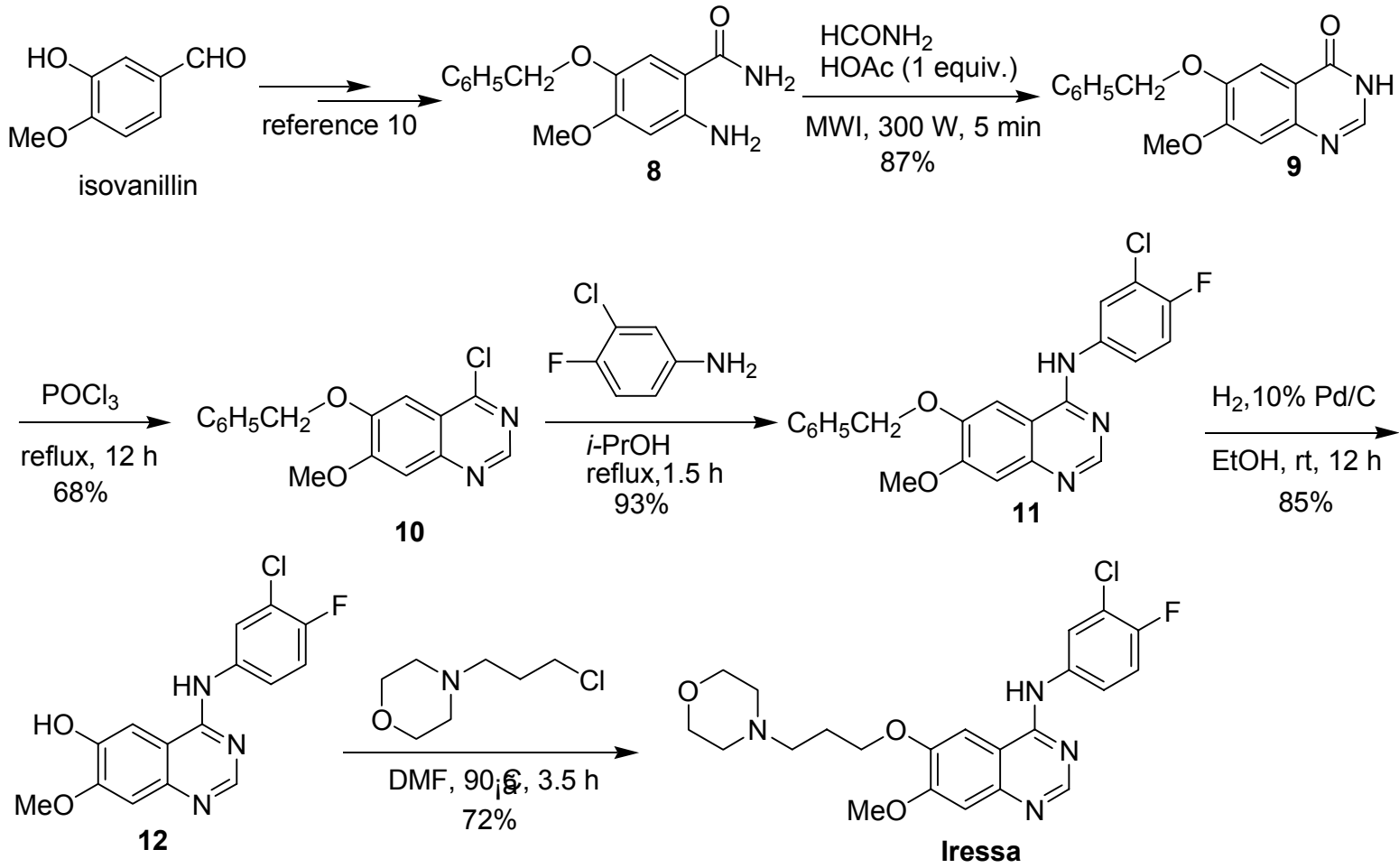

Scheme 2. Synthesis of Iressa. 


\section{Experimental Section}

General Procedures. All materials were of commercial quality and were used as received. Melting points were uncorrected. The product purities were determined by GC-MS analysis. GCMS data was acquired on a TOP series GC8000 with a FINNIGAN-VOYAGER mass selective detector. NMR data were acquired on a Bruker 500 or a Varian 400 spectrometers. ${ }^{1} \mathrm{H}$ and ${ }^{13} \mathrm{C}$ chemical shifts $(\delta)$ are reported in ppm relative to TMS as internal standard. Coupling constants $(J)$ are given in Hz. A modified domestic microwave oven adopted for refluxing was used for all the investigations and the reactions were monitored by thin layer chromatography coated with silica gel.

General procedure for synthesis of quinazolin-4(3H)-one. To the mixture of anthranilamide (0.68 $\mathrm{g}, 5 \mathrm{mmol})$ and an appropriate amide $(50 \mathrm{mmol})$ was added $5 \mathrm{mmol}$ of acetic acid, and the mixture was heated under microwave irradiation at 500 Watt for a few minutes. After the reaction was finished, the resulting mixture was poured into ice-cooled water and stirred for 30 min. The precipitation was filtered, and the filter cake washed with water to yield target molecules.

Quinazolin-4(3H)-one (1a). Yield, $93 \%$, white solid in a purity higher than 99\%, mp 215-216

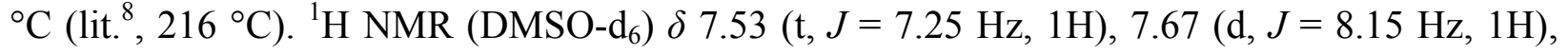
$7.82(\mathrm{~m}, 1 \mathrm{H}), 8.09 \sim 8.13(\mathrm{~m}, 2 \mathrm{H}), 12.24(\mathrm{~s}, 1 \mathrm{H}, \mathrm{NH})$; GC-MS m/z $146\left(\mathrm{M}^{+}\right)$.

2-Methylquinazolin-4(3H)-one (1b). Yield, $77 \%$, white solid in a purity higher than 98\%, mp 238-240 ${ }^{\circ} \mathrm{C}$ (lit. $\left..{ }^{15}, 240{ }^{\circ} \mathrm{C}\right) .{ }^{1} \mathrm{H}$ NMR (500 MHz, DMSO-d 6$) \delta 2.35$ (s, 3H), $7.45(\mathrm{~m}, 1 \mathrm{H}), 7.57$ $(\mathrm{d}, J=8.10 \mathrm{~Hz}, 1 \mathrm{H}),, 7.76(\mathrm{~m}, 1 \mathrm{H}), 8.08(\mathrm{~d}, J=7.75 \mathrm{~Hz}, 1 \mathrm{H}), 12.2(\mathrm{~s}, 1 \mathrm{H}, \mathrm{NH}) ;{ }^{13} \mathrm{C}$ NMR $(100$ MHz, DMSO-d $)_{6}: \delta 21.96,121.15,126.19,126.37,127.10,134.79,149.48,154.78,162.24$; GC$\mathrm{MS} m / z 160\left(\mathrm{M}^{+}\right)$.

2-Phenylquinazolin-4(3H)-one (1c). Yield, $63 \%$, white solid in a purity of 98.6\%, mp 242-246 ${ }^{\circ} \mathrm{C}$ (lit. $\left.{ }^{16}, 246{ }^{\circ} \mathrm{C}\right) .{ }^{1} \mathrm{H}$ NMR (DMSO-d 6$) \delta 7.56(\mathrm{~m}, 4 \mathrm{H}), 7.75(\mathrm{~d}, J=7.25 \mathrm{~Hz}, 1 \mathrm{H}), 7.84(\mathrm{~m}, 1 \mathrm{H})$, $8.18(\mathrm{~m}, 3 \mathrm{H}), 12.55(\mathrm{~s}, 1 \mathrm{H}, \mathrm{NH})$; GC-MS m/z $222\left(\mathrm{M}^{+}\right)$.

2-Cyanomethylquinazolin-4(3H)-one (1d). Yield, $78 \%$, white solid in a purity higher than 97\%, mp $242{ }^{\circ} \mathrm{C}$ (lit. $\left.{ }^{17}, 242-243{ }^{\circ} \mathrm{C}\right) .{ }^{1} \mathrm{H}$ NMR (DMSO-d 6$) \delta 4.18(\mathrm{~s}, 2 \mathrm{H}), 7.53(\mathrm{~m}, 1 \mathrm{H}), 7.68(\mathrm{~m}$, $1 \mathrm{H}), 7.82(\mathrm{~m}, 1 \mathrm{H}), 8.11(\mathrm{~d}, J=7.80 \mathrm{~Hz}, 1 \mathrm{H}), 12.46$ (s, 1H, NH); GC-MS m/z $185\left(\mathrm{M}^{+}\right)$.

General procedure for the synthesis of 2,2-disubstituted 2,3-dihydroquinazolin-4(1H)-ones 2. To a mixture of anthranilamide $(0.68 \mathrm{~g}, 5 \mathrm{mmol})$ and $p$-toluenesulfonic acid (17 $\mathrm{mg}, 0.1$ mmol) was added the required ketone. The mixture was heated under microwave irradiation at 60 Watt for $5 \mathrm{~min}$. The excess of ketone was removed under reduced pressure and the residues were washed with ether to afford target molecules.

2,2-Dimethyl-2,3-dihydroquinazolin-4(1H)-one (2a). Yield, 91\%, white solid in a purity higher than $99 \%$, mp $178-180{ }^{\circ} \mathrm{C}$ (lit. $\left.{ }^{4 \mathrm{~g}}, 183-184{ }^{\circ} \mathrm{C}\right) .{ }^{1} \mathrm{H}$ NMR $\left(500 \mathrm{MHz}, \mathrm{DMSO}-\mathrm{d}_{6}\right) \delta 1.56(\mathrm{~s}, 6 \mathrm{H})$, 3.5 (br, 1H, NH), 6.4 (br, 1H, NH), 6.62 (d, J=8.04 Hz, 1H), 6.83 (m, 1H), 7.29 (m, 1H), 7.88 
$(\mathrm{m}, 1 \mathrm{H}) ;{ }^{13} \mathrm{C}$ NMR $\left(100 \mathrm{MHz}, \mathrm{DMSO}-\mathrm{d}_{6}\right): \delta 29.52,67.36,114.36,114.77,116.97,127.72$, 133.72, 147.62, 163.61; GC-MS $m / z 176\left(\mathrm{M}^{+}\right)$.

2-Ethyl-2-methyl-2,3-dihydroquinazolin-4(1H)-one (2b). Yield, 95\%, white solid in a purity higher than 98\%, mp 178-180 ${ }^{\circ} \mathrm{C}$ (lit. $\left.{ }^{18}, 184-186{ }^{\circ} \mathrm{C}\right) .{ }^{1} \mathrm{H} \mathrm{NMR}\left(\mathrm{CDCl}_{3}\right) \delta 0.99(\mathrm{t}, J=7.15 \mathrm{~Hz}$, $3 \mathrm{H}), 1.49(\mathrm{~s}, 3 \mathrm{H}), 1.80(\mathrm{~m}, 2 \mathrm{H}), 3.80(\mathrm{br}, 1 \mathrm{H}, \mathrm{NH}), 6.49$ (br, 1H, NH), $6.62(\mathrm{~d}, J=7.25 \mathrm{~Hz}, 1 \mathrm{H})$, $6.80(\mathrm{t}, J=7.20 \mathrm{~Hz}, 1 \mathrm{H}), 7.28(\mathrm{~m}, 1 \mathrm{H}), 7.87(\mathrm{~m}, 1 \mathrm{H})$; GC-MS $m / z 190\left(\mathrm{M}^{+}\right)$.

$\mathbf{1}^{\prime} \boldsymbol{H}$-spiro[cyclohexane-1,2'-quinazolin]-4'(3'H)-one (2c). Yield, 91\%, white solid in a purity higher than $98 \%$, mp $226{ }^{\circ} \mathrm{C}$ (lit. $\left.{ }^{18}, 224-225{ }^{\circ} \mathrm{C}\right) .{ }^{1} \mathrm{H}$ NMR $\left(\mathrm{CDCl}_{3}\right) \delta 1.25-1.42(\mathrm{~m}, 2 \mathrm{H}), 1.54-$ $1.63(\mathrm{~m}, 6 \mathrm{H}), 1.73-1.74(\mathrm{t}, J=6.35 \mathrm{~Hz}, 2 \mathrm{H}), 6.62(\mathrm{~d}, J=7.50 \mathrm{~Hz}, 2 \mathrm{H}), 6.80(\mathrm{t}, J=8.10 \mathrm{~Hz}, 1 \mathrm{H})$, $7.21(\mathrm{~m}, 1 \mathrm{H}), 7.56(\mathrm{~d}, J=7.50 \mathrm{~Hz}, 1 \mathrm{H}), 7.91(\mathrm{~s}, 1 \mathrm{H})$; GC-MS $m / z 216\left(\mathrm{M}^{+}\right)$.

2,2-Diphenyl-2,3-dihydroquinazolin-4(1H)-one coupled with DMF (2d-DMF). Yield, 66\%, white solid, mp 138-142 ${ }^{\circ} \mathrm{C} .{ }^{1} \mathrm{H}$ NMR $\left(\mathrm{CDCl}_{3}\right) \delta 2.88(\mathrm{~s}, 3 \mathrm{H}), 2.95$ (s, 3H), 5.20 (br, 1H, NH), $6.47(\mathrm{~s}, 1 \mathrm{H}, \mathrm{NH}), 6.70(\mathrm{~d}, J=8.05 \mathrm{~Hz}, 1 \mathrm{H}), 6.79(\mathrm{~s}, 1 \mathrm{H}), 7.26(\mathrm{~m}, 1 \mathrm{H}), 7.32-7.35(\mathrm{~m}, 6 \mathrm{H}), 7.40-$ $7.42(\mathrm{~m}, 4 \mathrm{H}), 7.80(\mathrm{~m}, 1 \mathrm{H}), 8.00(\mathrm{~s}, 1 \mathrm{H})$.

Typical procedure for $1 \mathrm{H}, 3 \mathrm{H}$-quinazolin-2,4-dione 3 (Table 3 , entry 1). To a mixture of anthranilamide $(0.68 \mathrm{~g}, 5 \mathrm{mmol})$ and urea $(1.20 \mathrm{~g}, 20 \mathrm{mmol})$ were added $5 \mathrm{~mL}$ of DMSO and acetic acid $(5 \mathrm{mmol})$. The mixture was heated under microwave irradiation at 300 Watt for 5 min. After completion of the reaction, the mixture was poured into ice-cooled water and stirred for $30 \mathrm{~min}$. The solid was filtered by suction, washed with cold water and dried at vacuum to afford the compound $\mathbf{3}$ in $88 \%$ yield as a white solid in $98 \%$ purity, mp $>280{ }^{\circ} \mathrm{C}$ (lit. ${ }^{19}, 342-343$ $\left.{ }^{\circ} \mathrm{C}\right) .{ }^{1} \mathrm{H}$ NMR $\left(500 \mathrm{MHz}, \mathrm{DMSO}-\mathrm{d}_{6}\right) \delta 7.18(\mathrm{~m}, 2 \mathrm{H}), 7.63(\mathrm{~m}, 1 \mathrm{H}), 7.89(\mathrm{~d}, J=9.75 \mathrm{~Hz}, 1 \mathrm{H})$, $11.14(\mathrm{~s}, 1 \mathrm{H}, \mathrm{NH}), 11.29(\mathrm{~s}, 1 \mathrm{H}, \mathrm{NH}) ;{ }^{13} \mathrm{C} \mathrm{NMR}\left(100 \mathrm{MHz}, \mathrm{DMSO}-\mathrm{d}_{6}\right): \delta 114.84,115.85$, 122.84, 127.47, 135.47, 141.39, 150.84, 163.37; GC-MS $m / z 162\left(\mathrm{M}^{+}\right)$.

4-(3'-Chloro-4'-fluoroanilino)-7-methoxy-6-(3-morpholinopropoxy)quinazoline (Iressa). $^{20}$ yellow solid, $\mathrm{mp}>250{ }^{\circ} \mathrm{C} .{ }^{1} \mathrm{H}$ NMR $\left(500 \mathrm{MHz}, \mathrm{DMSO}-\mathrm{d}_{6}\right) \delta 2.00(\mathrm{~m}, 2 \mathrm{H}), 2.35(\mathrm{t}, J=6.5 \mathrm{~Hz}$, 4H), $2.48(\mathrm{t}, J=6.5 \mathrm{~Hz}, 2 \mathrm{H}), 3.58(\mathrm{t}, J=4.5 \mathrm{~Hz}, 4 \mathrm{H}), 3.94(\mathrm{~s}, 3 \mathrm{H}), 4.18(\mathrm{t}, J=6.5 \mathrm{~Hz}, 2 \mathrm{H}), 7.22$ $(\mathrm{s}, 1 \mathrm{H}), 7.45(\mathrm{~m}, 1 \mathrm{H}), 7.80(\mathrm{~m}, 2 \mathrm{H}), 8.12(\mathrm{~m}, 1 \mathrm{H}), 8.50(\mathrm{~s}, 1 \mathrm{H}), 9.57(\mathrm{~s}, 1 \mathrm{H}) ;{ }^{13} \mathrm{C} \mathrm{NMR}(125$ MHz, DMSO-d d $_{\text {: }}$ 25.86, 53.38, 54.92, 55.77, 66.14, 67.08, 102.76, 107.18, 108.88, 116.29, $118.56,122.17,123.33,137.00,146.90,148.24,152.50,153.95,154.41,156.02$.

\section{Conclusions}

We have developed a convenient microwave-assisted synthesis of 2-substituted quinazolin4(3H)-ones 1, 2,2-disubstituted 2,3-dihydroquinazolin-4(1H)-ones 2 and 1H,3H-quinazolin-2,4dione 3. The method offers several advantages including good to high yields, cleaner products, a dramatic reduction in reaction time and an easy experimental work-up procedure. The synthesis of an important anticancer drug, Iressa, has been accomplished on the basis of the construction of the key intermediate 9 using our microwave heating protocol. 


\section{Acknowledgements}

We are grateful to the National Natural Science Foundation of China (No. 20372015) for financial support. F. Li thanks the young teacher fellowship from this university.

\section{References}

1. For a recent review, see: Michael, J. P. Nat. Prod. Rep. 2005, 22, 627.

2. (a) Camirand, A.; Zakikhani, M.; Young, F.; Pollak, M. Breast Cancer Res. 2005, 7, R570.

(b) Baselga, J.; Averbuch, S. D. Drugs 2000, 60, 33. (c) Kim, R.; Toge, T.; Surgery Today 2004, 34, 293.

3. For synthesis of quinazolin-4(3H)-ones, see: (a) Yoo, C. L.; Fettinger, J. C.; Kurth, M. J. J. Org. Chem. 2005, 70, 6941. (b) Kamal, A.; Reddy, K. S.; Prasad, B. R.; Babu, A. H.; Ramana, A. V. Tetrahedron Lett. 2004, 45, 6517. (c) Alexandre, F. R.; Berecibar, A.; Wrigglesworth, R.; Besson, T. Tetrahedron 2003, 59, 1413. (d) Shimizu, M.; Oishi, A.; Taguchi, Y.; Gama, Y.; Shibuya, I. Chem. Pharm. Bull. 2002, 50, 426. (e) Shalaby, A. A.; Ei-Khamry, A. M. A.; Shiba, S. A.; Ahmed, A. A. A. E. Arch. Pharm. Pharm. Med. Chem. 2000, 333, 365. (f) Stevenson, T. M.; Kazmierczak, F.; Leonard, N. J. J. Org. Chem. 1986, 51,616 .

4. For synthesis of quinazolin-2,4-diones, see: Connolly, T. J.; McGary, P.; Sukhtankar, S. Green Chem. 2005, 7, 586. (b) Schwinn, D.; Glatz, H.; Bannwarth, W. Helv. Chim. Acta 2003, 86, 188. (c) Shao, H.; Colucci, M.; Tong, S.; Zhang, H.; Castelhano, A. L. Tetrahedron Lett. 1998, 39, 7235. (d) Gordeev, M. F.; Hui, H. C.; Gordon, E. M.; Patel, D. V. Tetrahedron Lett. 1997, 38, 1729. (e) Gouilleux, L.; Fehrentz, J. A.; Winternitz, F.; Martinez, J. Tetrahedron Lett. 1996, 37, 7031. (f) Buckman, B. O.; Mohan, R. Tetrahedron Lett. 1996, 37, 4439. (g) Larsen, S. D.; Connell, M. A.; Cudahy, M. M.; Evans, B. R.; May, P. D.; Meglasson, M. D.; O'Sullivan, T. J.; Schostarez, H. J.; Sih, J. C.; Stevens, F. C.; Tanis, S. P.; Tegley, C. M.; Tucker, J. A.; Vaillancourt, V. A.; Vidmar, T. J.; Watt, W.; Yu, J. H. J. Med. Chem. 2001, 44, 1217. (h) Klemm, L. H.; Weakley, T. J. R.; Gilbertson, R. D.; Song, Y. H. J. Heterocycl. Chem. 1998, 35, 1269. (i) Sharma, S. D.; Kaur, V. Synthesis 1989, 677.

5. Wang, L.; Xia, J.; Qin, F.; Qian, C.; Sun, J. Synthesis 2003, 1241.

6. (a) Parkanyi, C.; Yuan, H. L.; Stromberg, B. H. E.; Evenzahav, A. J. Heterocycl. Chem. 1992, 29, 749. (b) Errede, L. A.; MeBrady, J. J.; Qien, H. T. J. Org. Chem. 1977, 42, 656.

7. For some recent reviews on this topic, see: (a) Roberts, B. A.; Strauss, C. R. Acc. Chem. Res. 2005, 38, 653. (b) E. 1. Ashry, E. S. H.; Ramadan, E.; Kassem, A. A. Adv. Heterocycl. Chem. 2005, 88, 1. (c) Molteni, V.; Ellis, D. A. Curr. Org. Synth. 2005, 2, 333. (d) Desai, B.; Kappe, C. O. Top. Curr. Chem. 2004, 242, 177. (e) de la Hoz, A.; Diaz-Ortiz, A.; Moreno, A. Chem. Soc. Rev. 2005, 34, 164. (f) Kappe, C. O. Angew. Chem. Int. Ed. 2004, 
43, 6250. (g) Ersmark, K.; Larhed, M.; Wannberg, J. Curr. Opin. Drug Discov. Dev. 2004, 7, 417. (h) Hayes, B. L. Aldrichchimica Acta 2004, 37, 66.

8. (a) Mizuno, T.; Iwai, T.; Ishino, Y. Tetrahedron Lett. 2004, 45, 7073. (b) Mizuno, T.; Ishino, Y. Tetrahedron 2002, 58, 3155. (c) Alexandre, F. R.; Berecobar, A.; Besson, T. Tetrahedron Lett. 2002, 43, 3911. (d) Orfi, L.; Waczek, F.; Pato, J.; Varga, I.; Hegymegi-Barakonyi, B.; Houghten, R. A.; Keri, G. Curr. Med. Chem. 2004, 11, 2549. (e) Montazeri N.; RadMoghadam, K. Phosphorus Sulfur Silicon Relat. Elem. 2004, 179, 2533.

9. (a) Li, F.; Meng, Q. Q.; Chen, H. S.; Li, Z. M.; Wang, Q. R.; Tao, F. G. Synthesis 2005, 1305. (b) Li, F.; Wang, Q. R.; Ding, Z. B.; Tao, F. G. Org. Lett. 2003, 5, 2169.

10. Stevenson, T. M.; Kazmierczak, F.; Leonard, N. J. J. Org. Chem. 1986, 51, 616.

11. Ife, M. R. J.; Brown, T. H.; Blurton, P.; Keeling, D. J.; Leach, C. A.; Meeson, M. L.; Parsons, I. E.; Theobald, C. J. J. Med. Chem. 1995, 38, 2763.

12. Althuis, T. H.; Hess, J. J. J. Med. Chem. 1977, 20, 146.

13. Matsuno, K.; Ushiki, J.; Seishi, T.; Ichimura, M.; Giese N. A.; Yu, J. C.; Takahashi, S.; Oda, S.; Nomoto, Y. J. Med. Chem. 2003, 46, 4910.

14. Murty, M. S. R.; Jyothirmai, B.; Krishna, P. R.; Yadav, J. S. Synth. Commun. 2003, 33, 2483.

15. Etter, M. C. J. Chem. Soc. Perkin Trans. 2 1983, 115.

16. Imai, Y.; Sato, S.; Takasawa, R.; Ueda, M. Synthesis 1981, 35.

17. Sumitomo Chem. DE 2005933, 1970; Chem. Abstr. 1970, 74, 65585.

18. Shi, D.; Shi, C.; Wang, J.; Rong, L.; Zhuang, Q.; Wang, X. J. Heterocycl. Chem. 2005, 42, 173.

19. Pakrashi, S. C.; Chattopadhyay, S.; Chakravarty, A. K. J. Org. Chem. 1976, 41, 2108.

20. Seimbille, Y.; Phelps, M. E.; Czernin, J.; Silverman, D. H. S. J. Label. Compd. Radiopharm. 2005, 48, 829 . 